\title{
JPEB
}

Jurnal Penelitian Ekonomi dan Bisnis, 4 (2), 2019, Hal: 65-77

http://www.jpeb.dinus.ac.id

\section{ANALISIS KINERJA EKONOMI SEBELUM DAN PADA ERA PENETAPAN KEISTIMEWAAN YOGYAKARTA}

\author{
Rosyid Nur Anggara Putra ${ }^{*}$ dan Muh. Rudi Nugroho ${ }^{2}$ \\ Fakultas Ekonomi dan Bisnis Islam, UIN Sunan Kalijaga Yogyakarta \\ Jalan Laksda Adisucipto, Daerah Istimewa Yogyakarta 55281, Indonesia \\ *Corresponding Email:rosyid.putra@uin-suka.ac.id
}

Diterima: Mei 2019; Direvisi: Agustus 2019; Dipublikasikan: September 2019

\begin{abstract}
This study aims to determine the level of success of economic performance before and in the era of Yogyakarta privileges determination. This study uses several relevant analytical methods to analyze economic performance. The economic performance will be observed through economic indicators and development indicators in support of the principle of the Specialties of Daerah Istimewa Yogyakarta (DIY). The methods applied in this research are description of indicators to provide a description of the performance of all activities carried out before and on the appointment of privilege, paired sample t-test to analyze situations that existed before and when implemented a police and Data Panel Regression Analysis. It was concluded that the adjustment funds before the dana istimewa (danais) had given good growth to DIY. DIY growth was seen after the danais program in 2013-2015 which increased by 0.98\%. This finding is in accordance with the expectations of researchers. Danais in the 2015 APBNP was recorded at 0.547 Trillion
\end{abstract}

Keywords: Economic Performance; Inequality; Growth

\begin{abstract}
ABSTRAK
Penelitian ini bertujuan untuk mengetahui tingkat keberhasilan kinerja ekonomi sebelum dan pada era penetapan keistimewaan Yogyakarta. Penelitian ini menggunakan beberapa metode analisis yang relevan untuk menganalisis kinerja ekonomi. Kinerja ekonomi akan diamati melalui indikator ekonomi dan indikator pembangunan untuk mendukung prinsip Keistimewaan Daerah Istimewa Yogyakarta (DIY). Metode yang digunakan dalam penelitian ini adalah deskripsi indikator untuk memberikan deskripsi kinerja semua kegiatan yang dilakukan sebelum dan pada penetapan keistimewaan, paired sample t-test untuk menganalisis situasi yang ada sebelum dan pada implementasi kebijakan dan Analisis Regresi Panel Data. Disimpulkan bahwa dana penyesuaian sebelum adanya danais telah memberikan pertumbuhan yang baik terhadap DIY. Pertumbuhan DIY terlihat setelah adanya program danais pada tahun 2013-2015 yang meningkat sebesar $0,98 \%$. Temuan ini sesuai dengan harapan peneliti. Danais pada APBNP-2015 tercatat sebesar 0,547 Triliun.
\end{abstract}

Kata Kunci: Kinerja Ekonomi; Ketimpangan; Pertumbuhan 


\section{PENDAHULUAN}

Penelitian ini bertujuan untuk mengetahui tingkat keberhasilan kinerja ekonomi sebelum dan pada era penetapan keistimewaan Yogyakarta. Daerah Istimewa Yogyakarta (DIY) merupakan salah satu daerah istimewa yang ada di Indonesia, hal ini berdasarkan Undang-Undang Nomor 3 Tahun 1950 tentang Pembentukan Daerah Istimewa Yogyakarta. Berbagai rangkaian dinamika politik mewarnai subtansi kebijakan Negara secara formal. Di satu sisi UU No 3 Tahun 1950 merupakan rujukan utama dalam konteks keistimewaan dan pembentukan Yogyakarta. Namun, di sisi lain UU tersebut tidak menggambarkan esensi keistimewaan Yogyakarta dan tidak menunjukkan perbedaan dengan daerah otonom lainnya.

Disahkannya UU No 13 Tahun 2012 oleh Presiden Susilo Bambang Yudhoyono diharapkan dapat memperkuat status keistimewaannya. Substansi kewenangan daerah keistimewaan terdiri dari lima aspek (Pasal 7 Ayat 2 UU No 13 Tahun 2012) yaitu Pertama, tata cara pengisian jabatan Gubernur dan Wakil Gubernur DIY yang diangkat melalui proses penetapan. Hal ini dilatarbelakangi oleh perjuangan masyarakat DIY yang menginginkan Sultan tetap sebagai kepala daerah. Melalui Undang-Undang Keistimewaan secara yuridis memperkuat legitimasi kedudukan Sultan dan Paku Alam yang bertahta sebagai yang berhak diajukan sebagai Gubernur dan Wakil Gubernur (Jaweng, 2013)

Kedua, kewenangan keistimewaan dalam segi kelembagaan pemerintah DIY atau sering disebut dengan Perda Istimewa (Perdais) pada Pasal 20 Ayat 2 Undang-Undang Keistimewaan. Tujuannya yaitu untuk mewujudkan efektivitas dan efisiensi penyelenggaraan pemerintahan dan pelayanan masyarakat berdasarkan prinsip responsibilitas, akuntabilitas, transparansi, dan partisipasi dengan memperhatikan bentuk dan susunan pemerintah asli. Ketiga, aspek budaya merupakan wacana yang sangat penting karena didalamnya terdapat trilogi budaya yaitu Kraton sebagai institusi adat yang menggambarkan karya adiluhur, Sultan sebagai mediator kosmologis antara misi Kerajaan Islam dengan realitas masyarakat yang pluralis, dan Pendidikan sebagai unsur transformasi modernitas di jalur pendidikan. Kemudian aspek keempat dan kelima yaitu kewenangan dibidang tata ruang dan aspek pertahanan keduanya sangat berkaitan erat. Hal ini disebabkan karena aspek tata ruang hanya terbatas pada pengelolaan dan pemanfaatan tanah Kesultanan dan tanah Pakualaman dan tidak diiringi dengan inventarisasi (melalui aspek pertahanan) terhadap aset tersebut. Mulai ditetapkannya Undang-Undang Nomor 13 Tahun 2012 tentang Daerah Keistimewaan merupakan momentum bagi DIY untuk mewujudkan kesejahteraan bagi masyarakatnya.

Keberhasilan implementasi kebijakan otonomi daerah ditentukan oleh berbagai faktor, salah satu diantaranya adalah kinerja ekonomi (Syaukani, 2005). Walaupun kinerja ekonomi bukanlah faktor yang paling dominan dalam menentukan keberhasilan implementasi kebijakan otonomi daerah namun perlu perhatian dan upaya untuk meningkatkan kinerja ekonomi, secara simultan juga harus dilakukan peningkatan faktor - faktor lainnya. Syaukani (2005) mengemukakan bahwa antara implementasi kebijakan otonomi daerah dan kinerja ekonomi dapat ditarik hubungan sebab akibat yang cukup signifikan. Antara kedua kondisi tersebut saling mempengaruhi, selain implementasi otonomi daerah dipengaruhi oleh kinerja ekonomi, sebaliknya kinerja ekonomi juga dipengaruhi oleh implementasi kebijakan otonomi daerah. Situasi ini diapresiasi pada pertumbuhan ekonomi yang merupakan cerminan kinerja ekonomi. Laju pertumbuhan ekonomi di D.I Yogyakarta menunjukkan pertumbuhan yang positif. Berdasarkan data dari Badan Pusat Statistik (BPS, 2014)perekonomian DIY tahun 2012 tumbuh sebesar 5,32 persen lebih tinggi dibandingkan tahun sebelumnya yang tumbuh sebesar 5,17 persen.

Dalam teori pembangunan dikenal 2 (dua) pilar yang turut memberikan kontribusi terhadap teori pembangunan. Pertama teori pembangunan dari pandangan tradisional yang lebih menitikberatkan peningkatan Produk Domestik Bruto (PDB) sebagai indikator pembangunan suatu daerah (Widodo, 2006). Kelemahan pandangan tradisional adalah mengabaikan fenomena atau masalah-masalah sosial seperti pengangguran, kemiskinan, 
ketimpangan pendapatan, dan lain-lain. Melengkapi kelemahan tersebut, maka munculah pandangan baru yaitu teori pembangunan modern tentang konsep pembangunan. Menurut pandangan ini, pembangunan harus dilihat sebagai sebuah upaya multidimensional yang meliputi perubahan pada berbagai aspek (struktur sosial, sikap masyarakat, serta institusi nasional tanpa mengabaikan tujuan awal yaitu pertumbuhan ekonomi, penanganan ketimpangan, serta perluasan kesempatan kerja).

Meskipun laju pertumbuhan ekonomi yang menunjukkan trend positif, namun tidak diimbangi dengan tingkat ketimpangan wilayah di DIY rendah. Di DIY sendiri masih terjadi kesenjangan ekonomi antar kabupaten/kota yang cukup tinggi. Hal ini disebabkan karena kondisi kabupaten/ kota di Propinsi DIY yang relatif berbeda. Ketimpangan antar wilayah di DIY yang diindikasikan oleh Indeks Williamson pada periode 2009-2013 menunjukkan tren peningkatan, yaitu dari 44,33 persen tahun 2009 menjadi 45,47 persen tahun 2013 . Ketimpangan regional kabupaten/kota di D.I Yogyakarta setiap tahunnya mengalami peningkatan, kecuali pada tahun 2011 turun sebesar 0,02 persen. Hal ini menunjukkan bahwa konsentrasi pembangunan masih berpusat di wilayah perkotaan.

Dari informasi yang diuraikan diatas, maka substansi penelitian ini dibatasi pada "Analisis Kinerja Ekonomi Sebelum dan Pada Era Penetapan Keistimewaan Yogyakarta". Kinerja ekonomi akan diamati melalui indikator ekonomi makro dan indikator pembangunan di daerah. Dalam indikator ekonomi makro daerah, instrumen yang akan diamati yaitu pertumbuhan ekonomi, inflasi, dan penyerapan tenaga kerja. Kemudian, dalam penelitian ini juga akan dianalisis beberapa indikator pembangunan ekonomi. Instrumen yang akan diamati melalui indikator pembangunan ekonomi adalah distribusi pendapatan, tingkat kemiskinan, dan indeks pembangunan manusia.

Kondisi aktual yang diuraikan di atas merupakan masalah kini yang dihadapi oleh DIY dalam status Otonomi Khusus. Masalah tersebut adalah pertumbuhan ekonomi yang relatif tinggi tiap tahun di DIY, tetapi tidak diimbangi oleh instrumen ekonomi makro lainnya dan instrumen pembangunan. Fenomena ini barangkali berpotensi memperlebar persoalanpersoalan daerah. Dari rumusan permasalahan diatas, maka ada beberapa pertanyaan penelitian yang hendak akan dijawab yaitu: Bagaimana laju pertumbuhan indikator ekonomi antar kabupaten/kota sebelum dan pada era Penetapan Keistimewaan Daerah Istimewa Yogyakarta?

\section{TINJAUAN PUSTAKA}

\section{Teori Pertumbuhan Wilayah}

Untuk memperoleh kesesuaian dengan persoalan yang akan dikaji khususnya terhadap objek permasalahan dalam penelitian, maka akan dipaparkan teori pertumbuhan wilayah sebagai berikut:

1. Teori Pertumbuhan Wilayah Neoklasik

Teori Neoklasik mengasumsikan adanya fleksibilitas faktor harga yang sempurna, sehingga perpindahan tenaga kerja dan modal antar wilayah otomatis akan menghilangkan perbedaan faktor harga. Pendapatan perkapita antar wilayah pada akhirnya akan sama (Richardson, 1978). Teori ini menyatakan bahwa pertumbuhan wilayah ditentukan oleh tiga faktor antara lain tenaga kerja, ketersediaan modal, dan kemajuan teknologi. Selain itu, teori ini menekankan pentingnya perpindahan faktor produksi, khususnya tenaga kerja dan modal antar wilayah dan antarnegara.

2. Teori Ketidakseimbangan Pertumbuhan Wilayah

Teori ini muncul sebagai reaksi terhadap teori pertumbuhan wilayah Neoklasik. Menurut teori ketidakseimbangan pertumbuhan wilayah, kekuatan pasar tidak dapat menghilangkan perbedaan antar wilayah dalam suatu negara bahkan cenderung menciptakan dan memperburuk perbedaan antar wilayah. Menurut (Myrdal, 1957), terdapat dua kekuatan yang bekerja dalam proses pertumbuhan ekonomi yaitu efek balik 
negatif (backwash effect) dan efek penyebaran (spread effect). Konsep pemikiran Myrdal kemudian dilanjutkan oleh Hirschman (1958) dalam mengenalkan polarization effect dan trickling down effect.

Menurut Myrdal dan Hirchman, efek pertama kurang menguntungkan bagi proses pertumbuhan ekonomi yaitu berupa adanya aliran modal dan tenaga kerja dari wilayah sekitar yang kurang berkembang ke wilayah inti yang relatif maju. Efek kedua merupakan pengaruh yang menguntungkan, mencakup kegiatan aliran investasi dari wilayah inti ke wilayah sekitar.

3. Teori Pertumbuhan Struktur Ekonomi

Studi empiris mengenai pertumbuhan ekonomi dan perubahan struktural ini telah banyak dilakukan antara lain oleh Fisher (1935), Clark (1949), Lewis (1954), Kuznets (1973), Chenery \& Syrquin (1975). Hasil penelitian Fisher (1935), mengemukakan bahwa pertumbuhan ekonomi disertai dengan pergeseran permintaan dari sektor primer ke sektor sekunder dan akhirnya ke sektor tersier. Hal ini mengakibatkan perubahan dalam struktur produksi melalui pergeseran kesempatan kerja dan alokasi dana. Clark tahun 1949 mengadakan pendekatan tentang perkembangan proses ekonomi dan menyimpulkan bahwa makin tinggi pendapatan per kapita suatu negara makin kecil peranan sektor pertanian dalam mengyediakan kesempatan kerja (Budiharsono, 1989).

4. Teori Distribusi Pendapatan Antar Wilayah

Pembangunan ekonomi melalui pertumbuhan selama ini diyakini sebagai strategi pembangunan yang dalam jangka panjang dapat meningkatkan taraf hidup masyarakat melalui efek tetesan ke bawah (trickle down effect). Namun dari berbagai fakta menunjukkan bahwa manfaat pertumbuhan ekonomi kurang menyentuh pada kelompok masyarakat yang berpenghasilan rendah ataupun wilayah - wilayah yang kurang berkembang. Teori yang menjelaskan tentang distribusi pendapatan antar wilayah adalah Hipotesis U terbalik Kuznets(Kuznets, 1973)

Analisis Kuznets dalam penelitian antar negara bagian USA, menyatakan bahwa diantara faktor sosial, ekonomi dan politik yang mempengaruhi pola $U$ terbalik, terdapat dua faktor penting yaitu konsentrasi modal pada kelompok berpendapatan tinggi dan pergeseran penduduk (tenaga kerja) dari sektor pertanian tradisional ke sektor industri modern.

Menyangkut faktor konsentrasi modal, Kuznets mengasumsikan bahwa kelopmpok berpendapatan tinggi memberikan kontribusi modal dan tabungan yang besar, sementara modal dan tabungan dari kelompok lainnya sangat kecil. Untuk faktor pergeseran penduduk, menurut Kuznets timbul akibat pergeseran penduduk dari sektor pedesaan yang tradisional ke sektor perkotaan yang modern. Ketimpangan pendapatan meningkat karena produktivitas sektor industri perkotaan meningkat lebih cepat dibandingkan dengan produktivitas sektor pertanian di pedesaan (Kuznets, 1973).

\section{Ketimpangan Ekonomi}

Beberapa ahli ekonomi mengatakan bahwa ketimpangan pembangunan antar daerah timbul karena adanya perbedaan dalam kepemilikan sumber daya dan faktor produksi. Daerah yang memiliki sumber daya dan faktor produksi, terutama yang memiliki barang modal (capital stock) akan memperoleh pendapatan yang lebih banyak dibandingkan dengan daerah yang memiliki sedikit sumber daya(Yeniwati, 2013).

Ketimpangan pendapatan dapat terjadi antar individu, sektor, maupun daerah. Ketimpangan pendapatan di setiap daerah disebabkan perbedaan komposisi jumlah penduduk, sumber daya yang ada dan karakteristik setiap daerah. Ketimpangan tidak bisa dibiarkan tinggi karena dapat berdampak buruk terhadap kestabilan ekonomi dan politik (Yasa \& Arka, 2015). 
Rosyid Nur Anggara Putra dan Muh. Rudi Nugroho : Analisis Kinerja Ekonomi Sebelum dan Pada Era Penetapan Keistimewaan Yogyakarta

Teori Williamson mengungkapkan bahwa pada awal pembangunan akan terjadi disparitas regional yang tinggi dan pembangunan hanya terpusat pada daerah-daerah tertentu. Dimana pada tahap awal pertumbuhan ekonomi yang lebih maju maka keseimbangan antar daerah dan disparitas akan berkurang dengan signifikan. Menurut Kuncoro (2006)adanya perbedaan karakteristik dan hetergenitas merupakan salah satu faktor terjadinya kesenjangan antar wilayah. Oleh karena itu pemerintah pusat harus melakukan berbagai cara untuk menutup celah ketimpangan antar wilayah maupun antar kawasan. Cara-cara yang bisa dipakai adalah mentrasnfer sumber daya manusia yang potensial dan memberikan teknologi baru untuk meningkatkan kinerja daerah sehingga pertumbuhan ekonomi akan berjalan dengan cepat.

Menurut Kuznets ketimpangan dalam pembagian pendapatan cenderung bertambah besar selama tahap-tahap awal pembangunan, baru kemudian selama tahap-tahap lebih lanjut dari pembangunan berbalik manjadi lebih kecil, atau dengan kata lain bahwa proses pembangunan ekonomi pada tahap awal mengalami kemerosotan yang cukup besar dalam pembagian pendapatan, yang baru berbalik menuju suatu pemerataan yang lebih besar dalam pembagian pendapatan pada tahap pembangunan lebih lanjut (Kuncoro, 2006). Lebih lanjut Kuznets menerangkan bahwa kelompok pendapatan tinggi memberikan kontribusi modal dan tabungan yang besar sedangkan modal dari kelompok lainnya sangat kecil. Dengan kondisikondisi lain yang sama, perbedaan dalam kemampuan menabung akan mempengaruhi konsentrasi peningkatan proporsi pemasukan dalam kelompok pendapatan tinggi. Proses ini akan menimbulkan dampak akumulatif, yang lebih jauh akan meningkatkan kemampuan dalam kelompok pendapatan tinggi, kemudian akan memperbesar kesenjangan pendapatan dalam suatu negara (Kuncoro, 2006).

\section{METODE PENELITIAN}

\section{Metode Analisis}

Penelitian ini akan menggunakan beberapa metode analisis yang relevan untuk menganalisis kinerja ekonomi. Kinerja ekonomi tersebut akan diamati melalui indikator ekonomi dan indikator pembangunan yang diperoleh dari Badan Pusat Statistik Provinsi Daerah Istimewa Yogyakarta dalam mendukung prinsip Keistimewaan DI Yogyakarta, yaitu:

\section{Deskripsi Indikator}

Analisis ini digunakan untuk memberikan deskripsi kinerja semua kegiatan yang dilakukan sebelum dan pada penetapan keistiwewaan. Kemudian, dalam analisis ini tidak semua indikator kinerja diberikan deskripsinya, melainkan dibatasi pada deskripsi variabel yang diamati.

\section{Indeks Williamson dan Index Entrophy Theil}

Indeks Williamson, Untuk menganalisis ketimpangan pendapatan antar wilayah di Propinsi DIY digunakan Indeks Williamson (Susanti et. al, 1995)

$$
V_{W}=\frac{\sqrt{\left(Y_{i}-Y\right)^{2} \cdot F_{i} / n}}{Y}
$$

Dimana:

$$
\begin{array}{ll}
\text { Vw } & \text { : Indeks Williamson } \\
\text { Yi } & \text { : PDRB perkapita kabupaten i } \\
\text { Y } & \text { : PDRB perkapita Propinsi DIY } \\
\text { Fi } & \text { : Jumlah penduduk kabupaten i } \\
\text { n } & \text { : Jumlah penduduk Propinsi DIY }
\end{array}
$$


Kriteria ketimpangan adalah sebagai berikut :

a) Jika $0,1<\mathrm{Vw}<0,35$ maka tingkat ketimpangan termasuk ringan

b) Jika $0,35<\mathrm{Vw}<0,50$ maka tingkat ketimpangan termasuk sedang

c) Jika $\mathrm{Vw}>0,50$ maka tingkat ketimpangan termasuk berat

\section{Index Entrophy Theil}

Index Entrophy Theil digunakan untuk mengukur kesenjangan ekonomi regional digunakan rumus indeks Entrophy Theil(Ying, 1999).

$$
I(y)=\sum(y j / Y) \cdot \log \left[\frac{(y j / Y}{x j / X}\right]
$$

Dimana:

I(y) : Indeks Entrophy Theil

yj : PDRB perkapita kabupaten $\mathrm{j}$

Y : Rata - rata PDRB perkapita Propinsi DIY

xj : Jumlah penduduk kabupaten $\mathrm{j}$

$\mathrm{X} \quad$ : Jumlah penduduk Propinsi DIY

\section{Penyerapan Tenaga Kerja}

Penyerapan Tenaga Kerja merupakan isu perekonomian makro suatu daerah yang sangat penting. Pangsa sektoral dalam penyerapan tenaga kerja ditunjukkan oleh rumus:

Dimana:

$$
S T K_{i}=\frac{T K_{i}}{\sum_{i} T K_{i}}
$$

STKi = pangsa penyerapan tenaga kerja sektor $\mathrm{i}$

$\mathrm{TK}=$ jumlah penyerapan tenaga kerja sektor $\mathrm{i}$

Kemudian, untuk menghitung pertumbuhan penyerapan tenaga kerja sektoral dapat dihitung dengan menggunakan rumus:

$$
G T K_{i}=\frac{T K_{i . t}-T K_{i . t-1}}{T K_{i . t-1}} \times 100 \%
$$

Dimana:

GTKi : pertumbuhan penyerapan tenaga kerja sektor i

TKi.t : jumlah penyerapan tenaga kerja sektor i tahun $\mathrm{t}$

TKi.t-1 : jumlah penyerapan tenaga kerja sektor i tahun $\mathrm{t}-1$

\section{Ukuran Kemiskinan}

Untuk mengetahui ukuran kemiskinan digunakan kesenjangan kemiskinan pendapatan atau poverty gap (Meier, 1995). Poverty gap menghitung tranfer yang akan membawa pendapatan setiap penduduk miskin hingga tingkat diatas garis kemiskinan, sedemikian hingga kemiskinan dapat dileyapkan.Adapun persamaan poverty gap sebagai berikut (Coudouel, Hentschel, \& Wodon, 2001):

$$
P G=\frac{1}{n} \sum_{i=1}^{q}\left(Z-\frac{Y i}{Z}\right)
$$


Rosyid Nur Anggara Putra dan Muh. Rudi Nugroho : Analisis Kinerja Ekonomi Sebelum dan Pada Era Penetapan Keistimewaan Yogyakarta

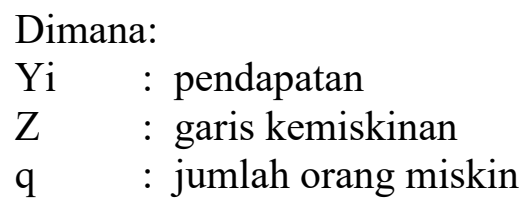

Pembilang pada persamaan di atas menunjukkan jurang kemiskinan (poverty gap), yaitu penjumlahan (sebanyak individu) dari kekurangan pendapatan orang miskin dari garis kemiskinan. Sedangkan penyebut adalah jumlah individu dalam perekonomian (n) yang dikalikan dengan nilai garis kemiskinan. Dengan ukuran ini, tingkat keparahan kemiskinan mulai terakomodasi.

\section{Indeks Pembangunan Manusia}

Indeks Pembangunan Manusia, Indeks Pembagunan Manusia (human development index, HDI) digunakan untuk membandingkan kinerja pembangunan manusia antardaerah di Provinsi DIY UNSFIR (2000) dalam Kuncoro (2006)IPM dapat dihitung dengan persamaan berikut ini:

Dimana:

$$
\mathrm{HDI}=1 / 3[\mathrm{X}(1)+\mathrm{X}(2)+\mathrm{X}(3)]
$$

$\mathrm{X}(1)$ : Indeks harapan hidup kelahiran

$\mathrm{X}(2)$ : Indeks pendidikan $=2 / 3$ (indeks melek huruf) $+1 / 3$ (indeks rata-rata lama sekolah)

$\mathrm{X}(3)$ : Indeks standar hidup layak

Kisaran antara nilai manimum dan maksimum untuk indikator yang tercakup sebagai komponen IPM adalah (UNSFIR, 2000):

Harapan hidup kelahiran $\quad: 25-85$ (standar UNDP)

Tingkat melek huruf $\quad: 0-100$ (standarUNDP)

Rata-rata lama sekolah : : 0-15 (standar UNDP)

Konsumsi per kapita yang disesuaikan: $300.000-732.720$

\section{Uji Beda Dua Rata-Rata.}

Uji Beda Dua Rata-Rata dilakukan untuk menganalisis situasi yang ada sebelum dan pada saat diimplementasikan suatu kebijakan. Analisis ini akan dilakukan untuk melihat indikator ekonomi dan indikator pembangunan suatu daerah.

\section{Analisa Regresi Data Panel}

Pengujian model dalam penelitian ini menggunakan analisa regresi data Panel dimana data diambil dari 5 (lima) kabupaten /kota di Provinsi DI Yogyakarta antara lain Kabupaten Gunung Kidul, Kabupaten Kulon Progo, Kabupaten Bantul, Kabupaten Sleman dan Kota Yogyakarta. Fokus penelitian ini adalah membandingkan pengaruh / dampak pemberlakuak keistimewaan Yogyakarta pada tahun 2014 terhadap tingkat kesejahteraan penduduk provinsi Yogyakarta yang dalam hal ini terwakili dengan variabel Pendapatan Perkapita penduduknya (Ycap). Sedangkan variabel independenntya terdiri Dana Istimewa dan Penyesuaiannya, Tingkat pengangguran, Tingkat kemiskinan dan Angka Partisipasi sekolah

\section{HASIL DAN PEMBAHASAN}

Dana penyesuaian adalah dana yang bersumber dari pendapatan APBN yang dialokasikan untuk mendukung program/ kebijakan tertentu pemerintah yang berdasarkan 
peraturan perundang-undangan kegiatannya sudah menjadi urusan daerah. Proxy dana penyesuaian dipilih karena masuk dalam format APBD transfer pemerintah lainnya yang bersamaan dengan dana otsus dan keistimewaan. Dari data dibawah adalah data sebelum dana keistimewaan, terlihat pertumbuhan ekonomi DIY yang diproksikan dengan PDRB per kapita, dan control variable yaitu Tingkat pendidikan, tingkat pengangguran, dan kemiskinan).

\section{Pendapatan Perkapita}

Dilihat dari pendapatan perkapita penduduk di wlayah DIY dari tahun $2010-2015$ mengalami kenaikan secara terus menerus, khususnya pada tahun 2014 ke 2015 semua kabupaten dan kota di wilayah DIY mengalami kenaikan yang signifikan. Selama lima tahun terakhir peringkat pendapatan perkapita dari tahun ke tahun tidak mengalami perubahan dari yang paling rendah pendapatan perkapitanya hingga yang paling tinggi di wilayah daerah istimewa yogyakarta adalah Kabupaten Kulonprogo, kabupaten bantul, kabupaten gunung kidul, kabupaten sleman, dan kota yogyakarta.

Dari data pendapatan perkapita di wilayah DIY ini juga bisa kita analisa berdasarkan indeks Williamson dan Indeks Entropy Thiel bahwa di wilayah DIY masi sangat terjadi ketimpangan pendapatan antar daerah yang cukup tinggi, misalnya kabupaten kulonprogo dengan kota Yogyakarta pada tahun 2010 dan 2011 perbandingannya 1 (satu) berbanding 3 (tiga) yaitu di tahun 2010 kabupaten Kulonprogo Rp. 129.200,00 sedangkan di kota Yogyakarta pendapatan perkapitanya sebesar Rp. 444.100,00. Bahkan sejak tahun 2012 sampai 2015 perbandingannya juga meningkat yaitu 1(satu) : 4 (empat), yaitu pada tahun 2015 kabupaten Kulonprogo Rp. 185.800,00 sedangkan di kota Yogyakarta pendapatan perkapitanya sebesar Rp. 651.500,00. Secara rinci gambaran pendapatan perkapita selama lima tahun terakhir di wilayah DIY sebagai berikut :

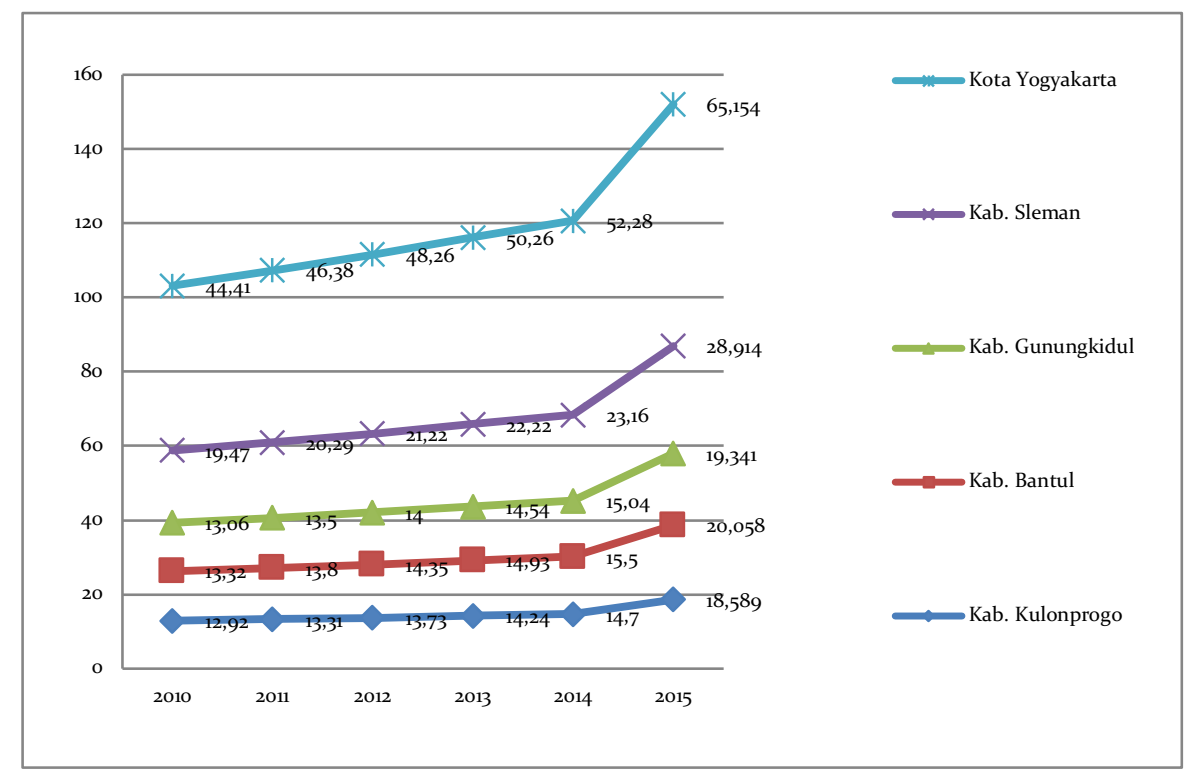

\section{Gambar 1. PDRB Perkapita Kabupaten/Kota di DIY Tahun 2010 - 2015}

\section{Tingkat Pendidikan}

Untuk mengukur tingkat pendidikan ini digunakam Indeks Pembangunan Manusia (IPM). IPM menjelaskan bagaimana penduduk dapat mengakses hasil pembangunan dalam memperoleh pendapatan, kesehatan, pendidikan, dan sebagainya. IPM diperkenalkan oleh United Nations Development Programme (UNDP) pada tahun 1990 dan dipublikasikan secara berkala dalam laporan tahunan Human Development Report (HDR). IPM dibentuk oleh 3 (tiga) dimensi dasar : Umur panjang dan hidup sehat, Pengetahuan, dan Standar hidup layak. 
Rosyid Nur Anggara Putra dan Muh. Rudi Nugroho : Analisis Kinerja Ekonomi Sebelum dan Pada Era Penetapan Keistimewaan Yogyakarta

IPM merupakan indikator penting untuk mengukur keberhasilan dalam upaya membangun kualitas hidup manusia (masyarakat/penduduk), sedangkan manfaat IPM antara lain : IPM dapat menentukan peringkat atau level pembangunan suatu wilayah/negara. Bagi Indonesia, IPM merupakan data strategis karena selain sebagai ukuran kinerja Pemerintah, dan IPM juga digunakan sebagai salah satu indikator penentuan Dana Alokasi Umum (DAU). Di wilayah provinsi DIY dari tahun 2010 sampai dengan 2015. Indeks pembangunan manusi mengalami kenaikan dari tahun ke tahun, data terakhir menunjukkan bahwa pada tahun 2015 IPM di Provinsi DIY mencapai 77, 59, secara rinci terlihat pada gambar berikut ini :

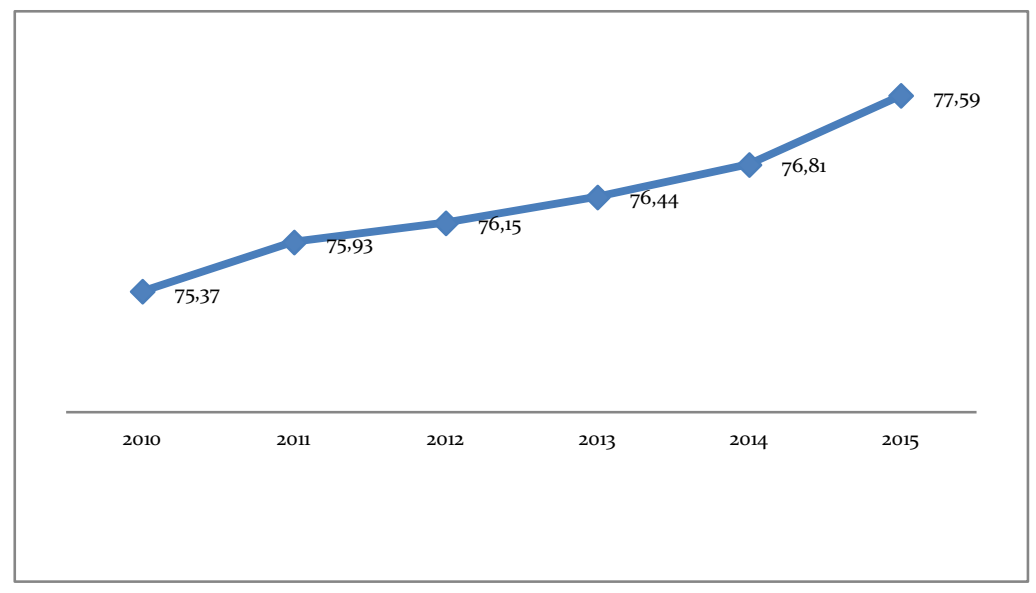

Gambar 2. Angka Indeks Pembangunan Manusia Provinsi DIY Tahun 2010 - 2015

\section{Pertumbuhan IPM}

Meskipun terlihat bahwa Angka Indeks Pembangunan Manusi Provinsi DIY ,meningkat terus selama 5 tahun terakhir, akan tetapi trend pertumbuhan IPM provinsi DIY belum terpola artinya pertumbuhannya masing sangat fluktuatif. Hal ini mengindikasikan bahwa ketiga indikator pembentuk IPM juga masih belum stabil yaitu Umur panjang dan hidup sehat, Pengetahuan, dan Standar hidup layak. Bahkan pada Tahun 2012 IPM Provinsi DIY pengalami pertumbuhan yang yang turun tajam dari 0,74 pada tahun 2011 menjadi 0,29 pada tahun 2012, setelah itu seiring waktu pertumbuhannya meningkat hingga pada tahun 2015 IPM provinsi tumbuh sebesar 1,02. Adapun fluktuatif pertumbuhan IPM dapat terlihat sebagai berikut :

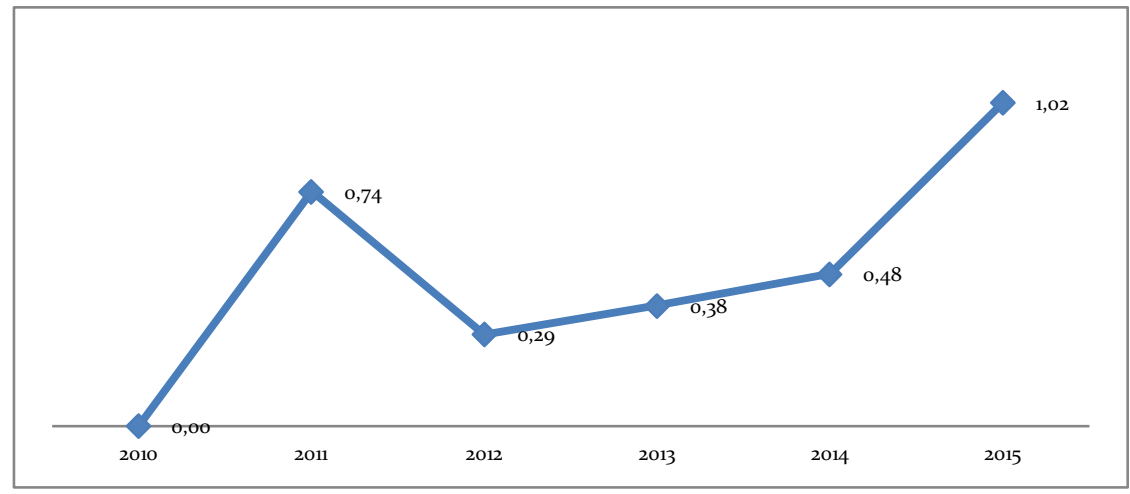

Gambar 3. Pertumbuhan Indeks Pembangunan Manusia Provinsi DIY Tahun 2010 - 2015 


\section{Tingkat Pengangguran}

Tingkat pengangguran di provinsi DIY dari tahun ketahun mengalami fluktuatif selama enam tahun terakhir, dikisarang angka 3,33 sampai 6,02. pengangguran teringgi selama enam tahun terakhir adalah pada tahun 2013 dimana angka pengangguran mencapai 6,02 dan terendah diamalami pada tahun 2014 diangka 3,33. Oleh karena itu diharapkan dengan adanya dana istimewa ini dapat menciptakan pertumbuhan ekonomi yang pada akhirnya dapat menurunkan angka pengangguran, meskipun pada tahun 2015 angka pengangguran naik nari tahun sebelumnya menjadi 4, 07. Secara rinci angka pengangguran dapat dilihat pada gambar di bawah ini :

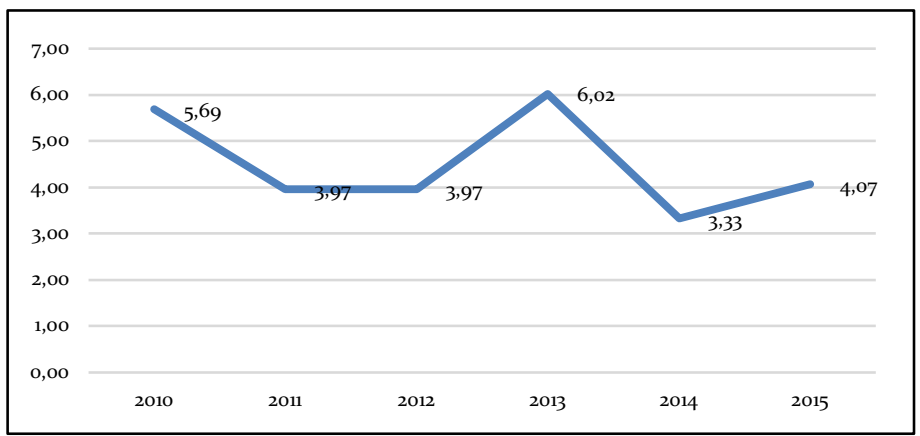

Gambar 4.

Pengangguran Provinsi DIY Tahun 2010 - 2015

Angka

\section{Indeks Ketimpangan Kemiskinan di DIY}

Poverty gap index mengukur tingkat kedalaman kemiskinan di suatu wilayah relatif terhadap garis kemiskinan. Indeks ini merupakan rata-rata proporsi poverty gap terhadap garis kemiskinan, di mana untuk penduduk tidak miskin nilai poverty gap adalah nol. Karena poverty gap $\mathrm{Gi}$ merupakan jarak antara pendapatan penduduk miskin terhadap garis kemiskinan, maka indeks ini sering dikaitkan dengan besarnya biaya yang dibutuhkan untuk mengentaskan kemiskinan. Untuk menghilangkan kemiskinan, secara sederhana besarnya biaya yang harus diberikan kepada penduduk miskin adalah sebesar jumlah dari poverty gap Gi. Indeks ini memenuhi kriteria focus axiom dan monotonicity axiom tetapi tidak memenuhi transfer axiom. Jika orang yang paling tinggi pendapatannya dalam kelompok penduduk miskin meningkat pendapatannya sehingga keluar dari kemiskinan maka besarnya indeks akan bertambah padahal headcount index akan menurun. Ini bertentangan dengan kriteria transfer axiom yang disebutkan di atas.

Jika dilihat dari Indeks ketimpangan kemiskinan antar kota dan desa di wilayah provinsi Daerah Istimewa Yogyakarta, tahun 2014 dan 2015, angka menunjukkan bahwa dibulan maret 2014 ketimpangan kemiskinan di kota lebih tinggi dari pada di desa yaitu angka ketimpangan di kota mencapai 2,22 dan ketimpangan di desa mencapai angka 2,11 akan tetapi jika kita meliat 6 bulan berikutnya, taitu pada bulan september 2014 angka ketimpangan kemiskinan berubah berkebalikan, yaitu angka kemiskinan di desa lebih tinggi dari pada di kota yaitu di desa 2,98 dan di kota 2,03. Dan kondisi ini berlanjut hingga bulan maret 2015 angka ketimpangan kemiskinan di desa sangat meningkat menjadi 3,7 dan ketimpangan kemiskinan di kota menjadi 2,55. Jika kita mengambil kesimpulan analisisnya bahwa pada awal sebelum dana istimewa ini di salurkan ketimpangan kemiskinan di desa lebih rendah dari pda di kota akan tetapi setelah di salurkan dana istimewa kondisinya berbalik arah dimana ketimpangan kemiskinan jadi lebih tinggi dari pada di kota. Hal ini dapat di simpilkan bahwa periode awal dana istimewa ini baru berdampak pada penduduk perkotaan saja belum mampu menyelesaikan ketimpangan kemiskinan di desa. Secara rinci perherakan ketimpangan kemiskinan dapat dilihat pada gambar berikut : 
Rosyid Nur Anggara Putra dan Muh. Rudi Nugroho : Analisis Kinerja Ekonomi Sebelum dan Pada Era Penetapan Keistimewaan Yogyakarta

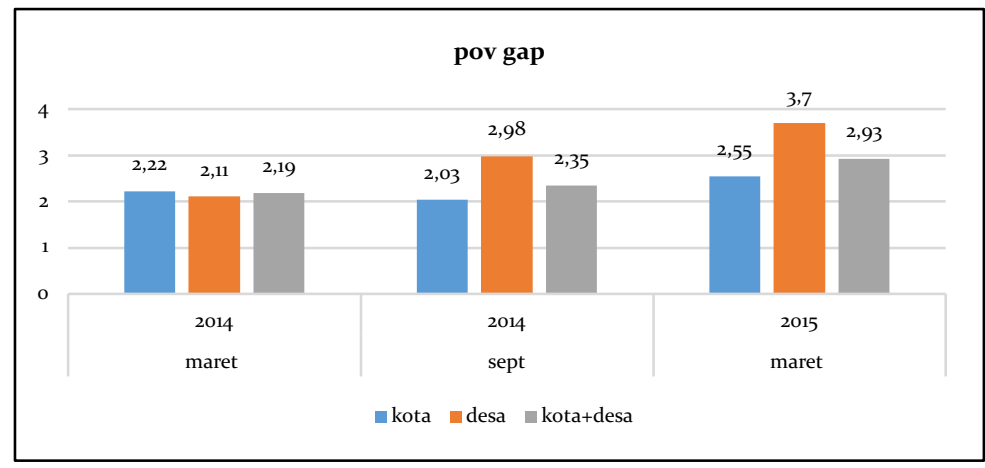

Gambar 5.

\section{Ketimpangan Kemiskinan di Provinsi DIY Tahun 2014 - 2015}

Angka

Pertumbuhan setelah (2013-2015) dan sebelum (2010-2012) adanya danais. Danais yang dipakai dalam penelitian ini adalah danais ditambah dana penyesuaian bersumber dari Laporan Keuangan Pemerintah Pusat Kementrian Keuangan. Transfer danais berdasarkan Peraturan Menteri Keuangan No.103/PMK.07/2013. Realisasi danais dimulai tahun 2013 sebesar 115 Milyar, tahun 2014 sebesar 419 Milyar dan tahun 2015 sebesar 547 Milyar.

\section{Kinerja Ekonomi Sebelum dan Setelah Penetapan Keistimewaan Yogyakarta}

Tabel 1. Hasil Analisis Regresi Data Panel Sebelum Dan Sesudah Keistimewaan Yogyakarta Tahun 2010 - 2015

\begin{tabular}{cccc}
\hline \multicolumn{2}{c}{ Sebelum $(2010-2012)$} & \multicolumn{2}{c}{ Setelah $(2013-2015)$} \\
\hline Variable & Coefficient & Variable & Coefficient \\
\hline C & 7.808778 & c & -3.025696 \\
Penyesuaian & $-0.035369^{*}$ & Danais & $0.985367^{*}$ \\
TPT & $-0.053536^{*}$ & TPT & $0.35769^{*}$ \\
TK & $-0.04005^{*}$ & Miskin & $0.042113^{*}$ \\
APS & $0.036501^{*}$ & APS & $-0.008065^{*}$ \\
\hline
\end{tabular}

Berdasarkan hasil koefisien regresi variabel Penyesuaian berpengaruh negatif dan signifikan terhadap pertumbuhan DIY sebelum danais tahun 2010-2012, akan tetapi setelah danais koefisien menjadi positif dan signfikan. Bisa disimpulkan bahwa dana penyesuaian sebelum adanya danais telah memberikan pertumbuhan yang baik terhadap DIY. Pertumbuhan DIY terlihat setelah adanya program danais pada tahun 2013-2015 yang meningkat sebesar $0,98 \%$. Temuan ini sesuai dengan harapan peneliti. Danais pada APBNP2015 tercatat sebesar 0,547 Triliun. Pertumbuhan ekonomi daerah dapat dipacu lebih tinggi lagi melalui ketepatan waktu dalam implementasi program dan kegiatan belanja pemerintah. Artinya, ada proses mempercepat efek multiplier dan pengurangan lag. Implementasi program tepat sasaran menyebabkan meratanya distribusi pendapatan per kapita di level kabupaten/kota dan berimplikasi pada naiknya kesejahteraan masyarakat. (lihat grafik 1.1)

Tingkat Pengangguran (TPT) dan Tingkat Kemiskinan (TK) berpengaruh negatif terhadap pertumbuhan ekonomi DIY sebelum adanya danais. Artinya jika TPT dan TK menurun 1\% maka pertumbuhan DIY tumbuh sebesar 0,05\% dan 0,04\% untuk masingmasing variabel dan Temuan ini menjelaskan sebelum adanya program danais, pemerintah DIY mampu menjalankan program pengentasan kemiskinan dan pemberdayaan masyarakat dengan baik. Akan tetapi temuan yang dihasilkan tahun 2013-2015 setelah adanya danais 
justru kebalikannya, TK dan TK yang meningkat justru mempengaruhi pertumbuhan DIY yang juga meningkat. Hal ini bisa dijelaskan bahwa belanja daerah bukan hanya untuk meningkatkan PDRB tetapi juga didistribusikan kepada masyarakat melalui penciptaan lapangan kerja yang luas.

Jika ekonomi tinggi dan pengangguran serta kemiskinan meningkat, artinya pertumbuhan tersebut tidak berkualitas. Turunnya kualitas pertumbuhan bisa disebabkan salah satunya rata-rata pendidikan tidak sesuai dengan permintaan industri. Jika mengacu pada Indikator IPM (Gambar 2) yaitu Angka Melek Huruf (AMH) menurun pada tahun 2015, tingkat pengangguran DIY naik pada tahun 2013 dan 2015. Prosentase penduduk miskin level kabupaten/kota hanya menurun pada tahun 2014. (lihat Gambar 4).

Angka Partisipasi Sekolah sebelum adanya danais berpengaruh positif dan signifikan terhadap Pertumbuhan DiY. Temuan in menjelaskan bahwa belanja daerah mengenai program-program pendidikan telah tepat sasaran. Investasi pendidikan harus menjadi kebijakan prioritas pemda DIY. Tingkat pendidikan tentu saja mampu meningkatkan kesejahteraan masyarakat salah satunya memenuhi kebutuhan permintaan sektor industri. Akan tetapi, hasil output statistik menjelaskan bahwa setelah adanya program danais, justru pertumbuhan DIY turun. Tingkat pendidikan yang tinggi ternyata belum mampu meningkatkan pertumbuhan DIY. Hal ini mengindikasikan bahwa sektor industri bukan hanya membutuhkan tingkat pendidikan, akan tetapi kemampuan (soft skill) juga menjadi pertimbangan utama perusahaan. Pemda DIY harus memberikan pelatihan kepada tenaga kerja agar mampu bersaing di dunia kerja dan program pemberdayaan masyarakat agar masyarakat mampu membuka lapangan kerja sendiri yang berimplikasi pada naiknya kesejahteraan. Pada grafik 1.4 Angka Partisipasi Sekolah di DIY sebelum adanya danais trend cenderung meningkat, setelah adaya danais meningkat tidak signfikan. Data ini sesuai dengan temuan output statistik. Indikator IPM yaitu RLS (rata-rata lama sekolah) juga menunjukkan adanya penurunan pada tahun 2014 .

\section{SIMPULAN}

Secara umum terdapat perbedaan kinerja keuangan sebelum dan pada era penetapan keistimewaan DIY. Dana Penyesuaian memiliki pengaruh negatif terhadap pertumbuhan DIY sebelum danais tahun 2010-2012, akan tetapi setelah danais pengaruh menjadi positif dan signfikan. Dapat disimpulkan bahwa dana penyesuaian sebelum adanya danais telah memberikan pertumbuhan yang baik terhadap DIY. Pertumbuhan DIY terlihat setelah adanya program danais pada tahun 2013-2015 yang meningkat sebesar 0,98\%. Temuan ini sesuai dengan harapan peneliti. Danais pada APBNP-2015 tercatat sebesar 0,547 Triliun. Pertumbuhan ekonomi daerah dapat dipacu lebih tinggi lagi melalui ketepatan waktu dalam implementasi program dan kegiatan belanja pemerintah. Artinya, ada proses mempercepat efek multiplier dan pengurangan lag. Implementasi program tepat sasaran menyebabkan meratanya distribusi pendapatan per kapita di level kabupaten/kota dan berimplikasi pada membaiknya kesejahteraan masyarakat dan juga membaiknya ketimpangan antar kabupaten atau kota dapat di perkecil. sehingga kedepan dengan keistimewaan yogyakarta ini memiliki dampak yang sangat posif di semua sektor khususnya sektor ekonomi.

\section{DAFTAR PUSTAKA}

BPS. 2014. D.I. Yogyakarta Dalam Angka 2014 / D.I. Yogyakarta in Figures 2014, 1-640. Budiharsono, S. (1989). Perencanaan Pembangunan Wilayah (Teori, Model Perencanaan, dan Penerapannya). Bogor: IPB.

Chenery, H., \& Syrquin, M. 1975. Pattemn of Development 1950-1970. (Oxford University Press., Ed.), A World Bank research publication. New York. Retrieved from http://documents.worldbank.org/curated/en/482491468328816108/Patterns-ofdevelopment-1950-1970 
Rosyid Nur Anggara Putra dan Muh. Rudi Nugroho : Analisis Kinerja Ekonomi Sebelum dan Pada Era Penetapan Keistimewaan Yogyakarta

Clark, C. O.1949. Application of Flood-Storage Accounting Methods. Transactions, American Geophysical Union. 30(4): 528-532. https://doi.org/10.1360/zd-2013-43-61064

Coudouel, A., Hentschel, J., \& Wodon, Q. 2001. Well-Being Measurement and Analysis.

Fisher, R. 1935. The Fiducial Argument in Statistical. Annals of Human Genetics. 6(4):391398.

Hirschman, A. 1958. The Strategy of Economic Development. (Y. U. Press, Ed.). New Haven.

Jaweng, R. E. 2013. Keistimewaan Yogyakarta: Babak Baru yang Menyisakan Sejumlah Catatan. Jurnal Ilmu Pemerintahan Indonesia. 42: 105-119.

Kuncoro, M. 2006. Ekonomi Pembangunan. Jakarta: Salemba Empat.

Kuznets, S. 1973. Modern Economic Growth. THe American Econonic Review, 63(3), 247258. https://doi.org/10.2307/1910352

Lewis, W. A. 1954. Economic Development with Unlimited Supplies of Labour. The Manchester School. 22(2): 139-191. https://doi.org/10.1111/j.14679957.1954.tb00021.x

Meier, G. M. 1995. Leading Issues in Economic Development (6th edition). Oxford: Oxford University Press.

Myrdal, G. 1957. Economic Theory and Under-Developed Regions. London: G. Duckworth.

Richardson. 1978. Regional \& Urban Economics. Penguin Books.

Susanti et. al, H. 1995. Indikator-Indikator Makroekonomi. Jakarta: Lembaga Penerbit FEUI.

Syaukani. 2005. Peningkatan Kinerja Eksekutif dan Implementasi Otonomi Daerah Desentralisasi dan Otonomi Daerah. Jakarta: LIPI Press.

Widodo, T. 2006. Perencanaan Pembangunan: Aplikasi Komputer Era Otonomi Daerah. Yogyakarta: UPP STIM YKPN.

Yasa, I. K. O. A., \& Arka, S. 2015. Pengaruh Pertumbuhan Ekonomi Dan Disparitas Pendapatan Antardaerah Terhadap Kesejahteraan Masyarakat Provinsi Bali. E-Jurnal Ekonomi Pembangunan Universitas Udaya. 4(2): 129-137.

Ying, L. G. 1999. China's Changing Regional Disparities during the Reform Period. Economic Geography. 75(1): 59-70. 